\title{
US Withdrawal from Afghanistan: Latest Development and Security Situation (2020)
}

\author{
* Dr. Muhammad Tariq, PhD (Political Science) (Corresponding Author) \\ ** Dr. Muhammad Rizwan, Chairman \\ *** Dr. Manzoor Ahmad, Chairman
}

\begin{abstract}
This paper discusses the US engagement in Afghanistan with particular reference to their withdrawal within a specified period of fourteen months. An agreement has been reached between the US and Taliban on February 29, 2020, at Doha (Qatar) followed by the intra-Afghan talks, which is expected to bring lasting peace and stability in the country. The issues of deadlock between the Afghan government and the Taliban and the pandemic COVID-19 are some of the obstacles in the way of peace. The theory of bargain provides a theoretical framework for the paper. The paper focuses on the post-withdrawal scenario of the US troops and ground realities that will help in prognosticating the future of Afghanistan. Keeping in view the post-US-Taliban agreement, it is difficult to say with certainty that peace and stability may shape the future destiny of the country since more than 1,300 casualties have happened in Afghanistan during the last three months despite the singing of the agreement.
\end{abstract}

Keywords: US, Taliban, Afghanistan, Bargain, Peace

\section{Introduction}

The 9/11 attacks on the United States, made Afghanistan an important foreign policy concern of the US and started a military campaign against the Al-Qaeda and the Taliban government. During the period of about more than eighteen years, the US has lost 2,400 military personnel in Afghanistan as of April 30, 2020. The US has also spent $\$ 137$ billion for the process of reconstruction in Afghanistan. The government of the Taliban was replaced by an elected government resulting in the development of many sectors but the future of Afghanistan remains uncertain. The greatest effort of the US is to prevent any further attack on the United States enjoying sanctuary in Afghanistan or getting the support therefrom (Thomas, 2020). Now, the main concern of the US and its coalition partners is to bring political stability and peace in Afghanistan after they leave the country within a specific time frame. With this end in mind, they had to opt for entering into a bargain with the Taliban by signing an agreement.

Now, the military engagement of the US in Afghanistan is drawing near to an end as a consequence of February 29, 2020, US-Taliban agreement on the issues of counterinsurgency and withdrawal of the US and other foreign troops working under the nomenclature of the Resolute Support Mission (RSM). According to the terms and conditions of that agreement the US has agreed for the withdrawal of all its security forces from Afghanistan within 14 months while Taliban has pledged not to make allowance for other groups such as Al-Qaeda and other terrorist groups to utilize the Afghan soil for threatening the US and its allied forces. Taliban has also shown its agreement to allow the US to make recruitments, training, and disbursing of funds for security matters (Thomas, 2020). During the US-Taliban talks, the Afghan government was not a party to the agreement but the political analysts see the withdrawal of the US forces over a complex political settlement that would focus on some of the socio-political and humanitarian gains achieved since 2001. The US-Taliban provided a framework for the intra-Afghan talks scheduled to commence from March 10, 2020, but the talks could not be held for several hindrances:

a) The Taliban has changed its strategy of attacks from the US security forces to the Afghan government since the initiation of the talks.

\footnotetext{
* Education Department Mardan Email: tariqawkum252@gmail.com

** Department of Pakistan Studies Abbottabad University of Science and Technology, Abbottabad

*** Department of Political Science, AWKUM
} 
b) The dispute remains unresolved over the release of prisoners although both sides have released prisoners but not per the vision of the agreement.

c) A political crisis in the country remains ambiguous. The presidential election of September 2019 gave the mandate of presidentship to Ashraf Ghani in February 2020 but the same was rejected by his rival contesting candidate as fraudulent. The deadlock over the office of the presidency made Mike Pompeo, the Secretary of State to suspend the immediate $\$ 1$ billion US financial aid to Afghanistan scheduled for the current financial year.

d) The issue of COVID-19 is another contributory factor for delaying the development in the above talks.

e) Continuation of the acts of barbarism is another great hindrance in the way of peace as manifested by the acts of non-state actors on May 12, 2020, followed by another act of brutality on May 12, 2020.

f) The worsening law and order situation in the post-US-Taliban agreement resulting in more than 1,300 civilian casualties, is indicative of the fact that peace and stability will be a cry in the wilderness.

However, things are not clear since no proper implementation has been made over the USTaliban agreement as the shift of the Taliban has been diverted from the US troops to the Afghan government. The issue of prisoners' exchange is another area of concern for the Afghan government as both the government and the Taliban have their points of view. The elevation of two persons to the post of presidency also creates doubts about the holding of the intra-Afghan talks. This has resulted in the suspension of financial aid to Afghanistan. The issue of COVID-19 that has struck the whole world may also create further complications for the government of Afghanistan in further delaying the talks. Complete withdrawal of the US forces is viewed with great suspicion by the international community and regional actors whether this would bring peace and stability to Afghanistan or would further deteriorate the security situation in the country.

\section{US-Taliban Agreement}

The US-Taliban agreement was signed on February 29, 2020, in Doha by Zalmay Khalilzad and deputy leader of Taliban Mullah Abdul Ghani Baradar in the presence of several international observers and US Secretary of State, Mike Pompeo. As a part of this agreement, the Afghan government was urged to commence negotiations with the Taliban without preconditions and further delay. As per terms of the agreement the US agreed to reduce its forces from the current 13,000 to 8,600 in a period of 135 days and withdraw all forces within 14 months (Thomas, 2020). Other commitments of the agreement include the exchange of prisoners between the Afghan government and the Taliban and removal of US sanctions against the Taliban by August 27, 2020. Removal of the sanctions is subject to the initiation of intra-Afghan talks. The Taliban also showed their commitment that Afghan soil can never be used by either Al-Qaeda or other insurgent groups against attacks on the US forces and its allied members. Some parts of the agreement are confidential and are not be made public as far as their implantation and verification are concerned (Dozier, 2020). Michael Pompeo stated that all the members of the senate would get a chance to see those annexes though some members feel the necessity of classifying those annexes (Brufke, 2020). The security situation does not seem to improve in Afghanistan even after signing the agreement with the Taliban. Acts of terrorism compelled the US government to suspend some parts of the financial aid for the current year and the next year.

\section{Political Crisis and US Aid Suspension}

The political situation in Afghanistan got worsened during the presidential election of September 2019 when the result of February 18, 2020 elections made Ashraf Ghani as President of Afghanistan. His claim was rejected by his rival Abdullah Abdullah who declared the elections to be deceitful and announced to form his government (TOLO, 2020). Despite efforts by Khalilzad for making reconciliation between the two presidential candidates, both arranged their separate inauguration ceremonies on March 9, 2020. This still creates uncertainty in the country as to what sort of political government does Abdullah Abdullah wants who criticizes Ashraf Ghani for not sharing power in his previous tenure. Some critics describe the Afghan government as highly centralized and do not encourage compromise which would result in ethnic tensions (Massoud, 2020). On March 23, 2020, US Secretary of State, Pompeo paid a visit to Afghanistan and met both Ashraf Ghani and Abdullah 
Abdullah individually and together but could not succeed in securing an agreement between the two who remain at odds. Pompeo showed his great resentment and criticized the two candidates for not coming to terms as this would damage the Afghan government and shared interests of the US government. He added that the US and its coalition partners have made huge sacrifices of their lives and finance for the process of reconciliation and reconstruction of the country but of no avail. The leadership failure to come to terms directly threatens the US interest and this may compel them to review their policy of engagement in Afghanistan (Pompeo, 2020). Keeping in view the deadlock the US government suspended \$1 billion US assistance to Afghanistan scheduled for 2020 while another $\$ 1$ billion financial aid scheduled for 2021 was cut off. It is not clear which US assistance was reduced for Afghanistan whether security fund or fund meant for reconstruction (Landay, Mohammed, \& Ali, 2020). Pompeo further stated that the US is determined to revisit the aid reduction if the two leaders come to a settled agreement. Abdullah reported that progress was made on May 1, 2020, stating that they have developed consensus on a wide range of issues (TOLO, 2020).

\section{COVID-19 Pandemic}

COVID-19 has struck almost the whole world and particularly greatly affected countries include the US, Spain, Italy, Brazil, UK, and France. The cases reported in Afghanistan are over 2,300 as of May 1,2020 , though the cases may be more than this figure due to the limited range of testing capacity (Ahmadi \& Kakar, 2020). This has greatly affected the US-Taliban agreement and intra-Afghan talks as this would put a hindrance in the way of implementation of the intra-Afghan talks and withdrawal of US forces from Afghanistan (Neff \& Barnes, 2020). It is also important to mention that US President Donald Trump has referred to the fact that the pandemic has accelerated the withdrawal of US troops from Afghanistan (Lee \& Kube, 2020). The pandemic could either further disrupt the initiative of the peace process in Afghanistan or could help expedite the peace process and intraAfghan talks. In the past, the Taliban had been instrumental in targeting the health sector but the spokesman of the Taliban has announced to extend full support for combating the COVID-19 with their utmost zeal and energy (Sediqi \& Hakimi, 2020). It is also reported that Afghanistan may be more prone to the COVID-19 pandemic due to its poor health sector and sanitation system, while another important noteworthy thing is its porous border with Iran which is supposed to be the epicenter of the pandemic and where more than three million Afghan refugees live: more than 250,000 Afghan refugees have returned to their parent country from Iran since January 1, 2020 (Shah, 2020). Besides, other issues, the COIVD-19 has been one of the greatest obstacles in the way of the Afghan peace process and intra-Afghan talks with the main purpose of the exchange of prisoners and bringing stability in the country.

\section{U.S. Aid to Afghanistan}

The development of the economic sector is very important to the peace and stability of Afghanistan. Years of war have weakened the developmental sector and natural resources of the country (Thomas, 2020). Afghan economy has also been hit by a reduction in aid by the international donor agencies. It may decrease further as a result of the lockdown caused by the pandemic. The US government has disbursed $\$ 137$ billion aid for Afghanistan since the Financial year 2002, out of which about $63 \%$ was reserved for security measures and $26 \%$ for developmental purposes while the remaining $11 \%$ for civilian operations and humanitarian aid (SIGAR, 2020). The Trump administration in Financial Year 20121 requests \$ 4 billion for the ADNSF, \$250 billion in Economic Support Funds, and some smaller amount for counter-narcotics (CRS, 2020). These figures represent a decrease in the budget both from the budget of FY 2020 and FY 2019.

\section{Role of Regional Dynamics in Afghanistan}

Regional powers and the involvement of the international community are very important to the conflict in Afghanistan. The neighbouring state considered central to Afghanistan is Pakistan that has played an active role in the affairs of the Afghan government but by any means, it has played a negative role in Afghanistan (Thomas, 2020). Pakistan's negative role has been ascribed for maintaining close ties with the Afghan insurgent group of the Haqqani network (Clayton, 2020). The Afghan government along with the US officials ascribes much of the insurgency and prolonged existence either directly or indirectly to Pakistan; US President, Donald Trump has accused Pakistan of "housing the very terrorists that we are fighting" (House, 2017). According to the US officials, the terrorists have their sanctuaries in Pakistan but that charge has been rebutted by Pakistan saying that 
the Taliban have increased their influence in Afghanistan and hence has strengthened their territorial control over some areas (Clayton, 2018).

Instability in Afghanistan would have a great impact on the security paradigm of Pakistan as has been observed on many occasions. Pakistan has been struggling hard against the militants and insurgents on its own for long and has conducted many military operations against the insurgents with the last one as Operation Zarb-e-Azab that brought about fruitful results to Pakistan (Tariq, 2018). Pak-Afghan relations have adversely been affected by the presence of over ten lac $(100,0000)$ Afghan Refugees in Pakistan and the long and treacherous border of about $2574.95 \mathrm{~km}$ border (CRS, Forty years of Discussion: Pakistan, the United Nations, and others recognize the Durand Line as an international boundary, but Afghanistan does not 2019).

India's strategic involvement in Afghanistan makes the security concerns of Pakistan inclined towards the Taliban regime in Afghanistan as friendly and anti-Indian which would help normalize Pakistan's relations with Afghanistan. India's involvement in the affairs of Afghanistan and support by the US to India's diplomatic presence is an alarming point for Pakistan. India's strategic interest in Afghanistan stems out from border rivalry with Pakistan, which also compels India to strengthen its relations with Afghanistan and the Central Asian Republics (Tariq, 2015). It is also an admitted fact that India has been contributing to Afghanistan in the largest amount for the process of reconstruction but it has never shown its determination to establish the strongest defense relationship with Afghanistan. This shows the nefarious designs of India in ensuring its influence with Afghanistan just to encircle Pakistan both on its eastern and western borders (Tariq, 2015).

Pakistan's importance to peace and stability cannot be gainsaid on any occasion. During the initiation of the US-Taliban talks, the US government requested Pakistan to extend cooperation in the talks. Resultantly, Pakistan had to release Mullah Abdul Ghani Baradar in October 2018, who was captured in 2010 in Karachi in a joint US-Pakistan operation. Khalilzad stated that his release was made on his request and thanked Pakistan for the facilitation of the Taliban's travel to Doha for talks (Press, 2019). After signing the agreement, the report on Afghanistan by the Department of Defense appreciated the role of Pakistan in facilitating the reconciliation process by terming Pakistan's role as "constructive but limited" (DOD, 2020). So, the role of Pakistan is very central to the process of peace and stability in Afghanistan, which fact is also admitted by the US and allied forces. Without the support of Pakistan, it is very difficult to facilitate negotiations either between the US and Taliban or between the Taliban and Afghan government (Tariq, 2020).

Afghanistan's relations with other neighbouring countries remain cordial and friendly; particularly the post-Soviet states of Central Asian Republics whose role remains limited but could increase in the future (Hamidzada \& Ponzio, 2019). During the past years financial and material support to the Taliban have been observed from both Iran and Russia, which the US has warned the Afghan government, both Iran and Russia justify their assistance on the ground of the presence of the ISIS in Afghanistan(US Report, 2018). It is significant at this point to note that both Iran and Russia were opposed to the enthronement of the Taliban in the late 1990s but sensing their utility against the US and allied forces they jumped to the side of the Taliban on the pretext of ISIS presence in Afghanistan. Afghanistan may also develop cordial relations with China owing to the growing popularity of China in Asia and at the global level (Kelemen, 2020). Thus, Pakistan is not the only country that has a greater interest in Afghanistan due to its long porous border but some other countries such as the Central Asian Republics, Russia, Iran, and China may also have their vested interests there for strategic purposes.

\section{A Brief Outlook}

Just as the 9/11 episode, the February 29, 2020 US-Taliban Agreement makes a landmark in the international politics. It is a significant moment for both the US and Afghanistan as the US policy observed a change for the first time towards Afghanistan since 2001. The US declares it as "the first step" while political and security dynamics may change but the outcome is yet to come as to how is the agreement interpreted by the various parties and how do they show their commitment to it (Wheelbarger, 2020). The US-Taliban agreement envisions the intra-Afghan talks as necessary for the lasting peace and stability in Afghanistan but it will only be when it is given concrete manifestation. The COVID-19 is another important factor that could directly affect the security and political 
dynamics in Afghanistan including the US-Taliban Agreement, intra-Afghan talks, and US financial assistance to Afghanistan.

US officials are of the view that the Taliban will not pose any threat to the US forces in Afghanistan nor would they conduct attacks against the Afghan government as per the terms and conditions of the US-Taliban agreement. But things could change and take a different turn if the US can alter the nature of the deployment of the security forces or reduce the budget for the security forces. President Ashraf Ghani reiterates that they could not be able to support their army for six months if the US reduced or discontinued their financial aid (Iqbal, 2018). But still, it is not certain whether peace and stability will reign Afghanistan or not, it is to be decided in future after the withdrawal of the US forces from there (Tariq, 2105). The US is also doubtful about the future of Afghanistan after the US-Taliban talks followed by the intra-Afghan talks will be fruitful in bringing peace and stability or it would face the same fate of civil war and instability as in the post-Soviet withdrawal scenario. There are even apprehensions about the security forces and their capability to counter-terrorism and insurgency in the future.

Some of the basic issues that the government of Afghanistan can face include; sustainability and legitimacy of the central government, fear of external threat from the non-state actors, political instability coupled with dissensions, the competence of the elite class to have control over the government, ethnic divisions, and the threat of ISIS may put the stability of Afghanistan at jeopardy. If the US-Taliban and intra-Afghan talks don't succeed then the greatest threat may come from the various factions of Taliban as they have not yet been agreed over the exchange of prisoners. Either party has its reservations and mechanism about the release of prisoners which are not acceptable to the other party. The issue of pandemic COVID-19 is another hurdle in the way of peace and stability as Afghanistan is a war-stricken country where most of its population lives below the line of poverty. The longevity of the pandemic may be a deciding factor for the future destiny of Afghanistan. It will be pre-mature to prognosticate the future of Afghanistan before the withdrawal of the US forces from Afghanistan working under the nomenclature of the RSM. But one thing is very clear that if the Taliban are not given a share in the power of the government, they may pose threat to the stability of the country and civil war may overtake most of the provinces of Afghanistan.

The collapse of the Afghan security forces or the Afghan government may create significant issues for the United States, particularly in the post-US-Taliban security arrangements. There are also possibilities that the machinery of the government may fail and the Taliban may regain control over the country or some key parts of the country. President of Afghanistan has already shown his concern over the stopping of the US support in financial and security matters would fail their government and particularly the law enforcement agencies within six months. Both the Taliban and ISIS are at loggerheads with each other which may further exacerbate the security situation in the country. Afghanistan has also experienced the worst fate in 1989 in the post- Soviet withdrawal scenario. Though the Soviet forces withdrew from Afghanistan in February 1989 yet they continued their aid to Afghanistan for three years to support their communist government in Afghanistan but they could not sustain it for more than just three years. Following the disintegration of the Soviet Union in 1991, they could not continue their aid and a coalition of Mujahideen toppled down the government in 1992 (Clayton, 2019). Mujahideen fought against each other for gaining power and the country faced a complex situation of civil war, whereby the Taliban emerged on the scene, took control of the government, and offered sanctuary to Al-Qaeda. Close ties still exist between the Taliban and the AlQaeda even today as the Taliban have shouldered the responsibility of the guarantee that Al-Qaeda would not attack the US forces in Afghanistan in the future as per the terms and conditions of the current agreement (Clayton, 2020).

The Trump administration in 2018 described the US policy in Afghanistan as "grounded in the fundamental objective of preventing any further attacks on the United States by terrorists enjoying haven or support in Afghanistan" (State Department, 2018). Some critics have described it as a strategic "myth" and the "fallacy of haven" as a squabble for endless war based on unwarranted worst-case scenario assumptions (Thrall \& Goepner, 2018). Some other critics are of the view that US policy goals like countering narcotics and safeguarding human rights are not the objectives that the US security forces are to address (Glaser \& Mueller, 2019). In any case, the US administration is likely to reduce the US aid to Afghanistan in the face of the US-Taliban agreement followed by the 
Intra-Afghan talks and the pandemic COIVD-19. The pandemic may also expedite the withdrawal of the US forces from Afghanistan before the scheduled time frame of 14 months as has been indicted by the Trump administration.

In the wake of US-Taliban agreement, the government of the United States, the Congress, and other policymakers may reassess the extent of Afghanistan's success, to what extent the political outcome might harm or benefit the US interest, and the level of US engagement and involvement in attaining (Banks, 2018). It is an admitted fact that during the last three months, despite singing of the peace agreement between the US and Taliban, Afghanistan has faced a total of 1,293 civilian casualties, which include 760 injuries while the rest include more than 5, 00 death casualties including 152 children and 60 women (Jazeera, 2020). On May 1, 2020, the Taliban killed 13 Afghan soldiers in the province of Balkh while the Afghan security forces were able to put to death at least two Taliban in the province of Paktia (Jazeera, 2020). On 12 May 2020, three gunmen wearing the uniform of Afghan Police entered a maternity ward in Barchi Hospital in the western part of Kabul and killed 14 people including two new-born babies (Jazeera, Babies among 14 killed as gunmen attack maternity ward in Kabul, 2020). Barbarous acts like these further worsen the security situation in the country resulting in the atmosphere of mistrust where the policy of 'might is right' works in the area when any party finds opportunity. History of Afghanistan has been very complex in the past and remained confronted with many issues of insurgency and lawlessness (Tariq, 2018). Just as the post-Soviet withdrawal created a leadership vacuum and political instability in Afghanistan, there are apprehensions that Afghanistan may be faced with the same situation in the future. There is no surety whether the US will continue its financial aid or not in the aftermath of the withdrawal scenario. It is also not certain whether the US will completely withdraw its forces or would leave some of the forces in the name of RSM to have their presence in the region for strategic purposes.

\section{Conclusion}

Even though the US and NATO have spent almost more than 18 years in Afghanistan but peace and stability still does not persist in the country. During their stay, the US has spent a huge amount in Afghanistan for the process of reconstruction and bringing in political stability and peace. Political stability is a far cry in Afghanistan which fact is clear from the office of presidency when in the elections of September 2019, Ashraf Ghani was declared as the winning candidate but his position was questioned by his rival Abdullah Abdullah and ultimately both took charge of presidency in February 2020. Another important development is the US-Taliban agreement on February 29, 2020, which further provides for the intra-Afghan talks for restoring peace and stability in the country. Two hurdles stand in the way of peace and stability; deadlock between Taliban and Afghan government over the issue of prisoners' exchange, and the pandemic COVID-19 that has caused lockdown in the country since both the parties are unable to carry on their dialogue further. The US government is also pressurizing the Afghan government to carry forward their talks with the Taliban and find a peaceful solution to the Afghan stalemate.

The most agonizing fact is the worsening of the security situation in Afghanistan despite the US-Taliban agreement, followed by the intra-Afghan talks in February 2020. Law and order situation has not improved, rather security has been exacerbated. A clear example of this is the number of casualties that have struck the country in the post-US-Taliban agreement. Till April 27, 2020, the number of civilian casualties stands at 1,293, out of which the number of injured people is 760 and more than 5, 00 death casualties including 152 children and 60 women. The occurrence of another brutal act on May 12, 2020, when three gunmen killed 14 innocent people while attacking a charity hospital at Barchi, the western part of Kabul. The killed people also included two new-born babies, which is a heart-touching incident. Now, the question is who is to be blamed for these barbarous attacks though efforts are underway to bring peace and stability in the country. Whether the US withdraws or stays away at Afghanistan, peace and stability seem to be a far cry in the war-stricken country of Afghanistan. The government is not only facing threat from the Taliban but also the ISIS. Another embarrassing fact is the tussle between the Taliban and ISIS, which may again destine the country towards civil war. The increased role of India, Iran, and Russia is also alarming for the prospects of Afghanistan as they may tilt either towards the Taliban or the ISIS or even towards the Afghan government or the US or vice versa. 


\section{References}

Afghanistan Turmoil and its Implications for the Security of Pakistan (2009-2016). (Tariq, 2018). Ph. D Dissertation, Mardan, Khyber Pakhtunkhwa, Pakistan: Abdul Wali Khan University.

Ahmadi, B., \& Kakar, P. (2020, April 16). "Coronavirus in Afghanistan: An Opportunity to Build Trust with the Taliban"? United States Institute of Peace.

Banks, J. (2018, October 23). "The Public Deserves an Afghanistan War Progress Report. National Review.

Brufke, j. (2020, March 3). "House Republicans sound the alarm on Taliban Deal, ". The Hill.

Clayton, T. (2018, February 21). (P. M. Officials, Interviewer) Rawalpindi, Punjab, Pakistan.

Clayton, T. (2019). Afghanistan: Background and U.S. Policy. Congressional Research Service,www.crs.gov.

Clayton, T. (2020). CRS In Focus IF10604, Al-Qaeda, and Islamic Affiliation in Afghanistan.

CRS. (2020). CRS Report R45329, Afghanistan: Issues for Congress and Legislation 2017-2019.

CRS. (2019, June 20). Forty years of Discussion: Pakistan, the United Nations, and others recognize the Durand Line as an international boundary, but Afghanistan does not.

DOD. (2020, January 23). Enhancing Security and Stability in Afghanistan, .

Dozier, K. (2020, February 15). "Secret Annexes, Backroom Deals: Can Zalmay Khalilzad Deliver Afghan Peace for Trump?". Briefing with Senior Administration Officials.

Glaser, J., \& Mueller, J. (2019, September 13). "Afghanistan: A Faliure to Tell the Truth". LobeLog.

Hamidzada, H., \& Ponzio, R. (2019, August). Central Asia's Growing Role in Building Peace and Regional Connectivity with Afghanistan.

House, W. (2017, August 21). Remarks by President Trump on the Strategy in Afghanistan and South Asia.

Iqbal, A. (2018, January 18). "Afghan Army to Collapse in Six Months Without US Help: Ghnai". Rawalpindi, Punjab, Pakistan: Dawn.

Jazeera, A. (2020, April 27). Afghan war killing civilians despite the US-Taliban peace deal. Al Jazeera TV.

Jazeera, A. (2020, May 12). Babies among 14 killed as gunmen attack maternity ward in Kabul. Al Jazeera TV.

Jazeera, A. (2020, May 1). Taliban Kills 13 Afghan soldiers in Balkh province. A: Jazeera TV.

Kelemen, B. (20120, January 21). "China's Economic Stabilization Efforts in Afghanistan: A New Party to the Table?". Middle East Institute.

Landay, J., Mohammed, A., \& Ali, I. (2020, April 5). "Executive: Planned \$1 billion U.S.aid cut would hit Afghan security forces funds". Reuters.

Lee, C. E., \& Kube, C. (2020, April 27). "Trump tells advisors U.S should pull troops as Afghanistan COVID-19 outbreaK LOOMS. NBC News.

Massoud, A. (2020, April 14). "What is Missing from Afghan Peace Talks". New York Times.

Neff, T. G., \& Barnes, J. (2020, March 18). "Coronavirus Disrupts Withdrawal in Afghanistan,".

New York Times.

Pompeo, M. (2020, March 23). "On the Political Impasse in Afghanistan". Secretary of State, State Department.

Press, T. H. (2019, February 9). Mullah Baradar released by Pakistan at the behest of the US: Khalilzad.

Sediqi, A. Q., \& Hakimi, O. (2020, March 18). "Coronavirus makes the Taliban realize they need health workers alive not dead". Reuters.

Shah, J. e. (2020, April 2). International Organization on Migration Return of Undocumented Afghans Weekly Situation Report Aril 12-18, 2020, see Jaffer Shah et al, "COVID-19: the current situation in Afghanistan,". The Lancert.

SIGAR. (2020, April 30). Quarterly Report to the United States Congress.

State, D. o. (2018, September 27). Integrated Country Strategy: Afghanistan. U.S Department of State.

Tariq, M. (2018). An Analysis of Insurgency in Afghanistan (2001-2016). (Hafeezullah, Ed.) Global Social Sciences Review, III (II), 131-145.Tariq, M. (2015). Dynamics of NATO Drawdown 
from Afghanistan and Future Implications. (R. Sultan, Ed.) FWU Journal of Social Sciences, $1(1)$.

Tariq, M. (2015). India-Pak Rivalry in Afghanistan. (R. Sultana, Ed.) FWU Journal of Social Sciences, 1 (2, Special Issue, NATO Drawdown from Afghanistan: Opportunities and Challenges), 15-24.

Tariq, M. (2020). The Borderland Theory in the context of Pak-Afghan Border. (D. M. Idrees, Ed.) Sir Syed Journal of Education and Social Sciences, 3 (1).

Thomas, C. (2020). Afghanistan: Background and U.S. Policy: In Brief. Congressional Research Service http://crsreport.congress.gov.

Thrall, A. T., \& Goepner, E. (2018, September 11). "Another Year of the War in Afghanistan".

TOLO. (2020, February 18). Abdullah Rejects Results. Announces Formation of "Inclusive Govt". TOLO News.

TOLO. (2020, May 1). Abdullah Reports Progress in Political Negotiations. TOLO News.

U.S. (2018, October 23).

Wheelbarger, K. (2020, March 10). Testimony before the House Armed Service Committee. 